\title{
Character Building of Students During the Covid-19 Pandemic Through Civic Education Learning
}

\author{
Theodorus Pangalila ${ }^{1, *}$ Darmawan Edi Winoto ${ }^{2}$
}

\author{
${ }^{1,2}$ Universitas Negeri Manado \\ ${ }^{*}$ Corresponding author. Email: theopangalila@unima.ac.id
}

\begin{abstract}
The Covid-19 pandemic that hit all countries globally has had a significant impact on education. Online learning at home brings fundamental problems for students, especially in shaping the character building of students. The purpose of this study was to determine how to improve student character through Civic Education learning. The Covid-19 pandemic has brought about significant changes in the paradigm and learning process. This research is a type of qualitative research with a descriptive approach. Data in this research was carried out through observation, interviews, and documentation study. The data in this study were analysed using the Miles and Huberman approach, namely through three activities that occur simultaneously: data reduction, data presentation, concluding/verification. The research found many problems that Civic Education teachers faced in learning during the Covid-19 pandemic. There were difficulties in building student character because there was no face-to-face between teachers and students.
\end{abstract}

Keywords: Character, Civic Education Learning, Covid-19 Pandemic.

\section{INTRODUCTION}

Every country globally is currently faced with a severe problem and requires full attention to solve it. Problems terse but Corona Virus Disease 2019, or that we are familiar with Covid-19 [1]. On January 30, 2020, WHO declared the COVID-19 outbreak in China an International Public Health Emergency that poses a high risk for countries with vulnerable health systems [2]. According to UNICEF: "A novel coronavirus (CoV) is a new strain of coronavirus. The disease identified in Wuhan, China, has been named coronavirus disease 2019 (COVID-19). 'CO' stands for corona, 'VI' for the virus, and 'D' for disease. Formerly, this disease was referred to as '2019 novel coronavirus' or '2019-nCoV.' The Covid 19 virus is a new virus linked to the same virus as Severe Acute Respiratory Syndrome (SARS) and some types of the common cold." [3] The coronavirus that causes Covid-19 was first reported in Wuhan, China, where the first person infected with the virus occurred on November 17, 2019. Since the first case in China, the spread of Covid-19 has continued to spread throughout the world and become a global pandemic. The Covid-19 pandemic has brought many changes to the life order of the world community [4]. This epidemic also resulted in fundamental policy changes in various lines, starting from education policies, economic policies and other policies affected by the virus.
As a result of the direction virus, Corona or Covid-19 is no exception in Indonesia, and the Indonesian government has taken several policies to cut transmission Covid-19. Its central policy is prioritising people's health and safety-work, worship and study from home. Corovirus has a huge impact on all aspects of life, including the world of education. The Indonesian government has made a policy to fight Covid-19 together. The most common policies include prohibiting people from doing activities that involve many people, implementing social distancing, physical distancing, limiting leaving the house and working from home and maximizing activities that allow it to be carried out remotely through an online system [5]. According to data from UNESCO, the Covid-19 pandemic has brought threats to $577,305,660$ students, ranging from preprimary education to high school students and $86,034,287$ students from Universities around the world. The Ministry of Education and Culture (Kemendikbud) stated that 68 million students ranging from early childhood education (PAUD) to high school (SMA) in Indonesia were affected by the corona virus pandemic (Covid-19). They were all forced to study from home.

The coronavirus pandemic has caused the learning process to temporarily suspend teaching and learning activities. They were learning to be done in their respective homes with the help of gadgets. Instead, the 
learning process is carried out online or e-learning, allowing it to be carried out from home or remote learning. As a result of the coronavirus pandemic, "the Minister of Education and Culture, Nadiem Anwar Makarim issued Circular Number 4 of 2020 concerning Implementation of Education in Emergency Times Coronavirus Disease (Covid-19)." The circular contains the implementation of educational policies, where the learning process from home or using el earning during the Covid-19 emergency period. Circular content is relevant to the learning process. "First, a home study is conducted through online learning so as to allow students to be facilitated in getting a meaningful learning experience. All classroom support curriculum services are provided and completed. Second, a home study can focus on the education of life skills, including those related to the Covid19 pandemic. Third, home-based learning activities and tasks can vary from student to student based on interests and conditions, including considering gaps in access/learning facilities at home; Fourth Evidence or products of learning activities from home are given qualitative and valuable feedback from the teacher, without being required to provide a quantitative score/value" [6].

The Minister of Education and Culture emphasized that "the teaching and learning process is carried out with the aim of providing a valuable learning experience for students by not burdening them with demands to complete the entire curriculum for graduation and grade promotion." "The online/distance learning process focuses on increasing students' understanding of the corona virus and its impact on health. The teaching and learning process must be adapted to the conditions and interests of each. Learning activities and assignments can be distinguished from one student to another. may differ between students. Although many schools practice the teaching and learning process from home, teachers are required to not only give assignments to students. But also interact and communicate to help students in doing their assignments."

Based on the circular above, it is clear that there is a learning process that is students' character development. Still, the online learning carried out by each school is only for students' cognitive development. Students are only given assignments, and the teacher explains each subject, without asking whether the student has taken a shower or if the student is already in a suitable place to study, even though the task of a teacher is not only to build students' cognitive but also to be able to build and instil values, good personality traits for students, and that is part of the main task of a natural educator.

Online learning at home brings fundamental problems for students, especially in shaping the character building of students. Therefore, a da is some educational value character. Some became a tool future pandemic covid 19th-first discipline; discipline refers to obeying and orderly students obeying the rules. Students are accustomed to following the directions in face-to-face learning situations by wearing a uniform according to the schedule and a hat during the flag ceremony. Suddenly during the Covid-19 pandemic, they studied at home without wearing a uniform. Of course, the atmosphere is different. Second, be honest. When doing exams or doing assignments from teachers, students tend to do the questions seriously because the teacher monitors them in class. It is different when taking online exams. The seriousness of students in taking exams decreases and even invites students to do plagiarism because without supervision from the teacher, even though their parents are there, the management of teachers and parents is different. The third is responsibility. In the face-to-face student system, there is usually a daily picket activity. This is intended to train students to be responsible for their duties, in contrast to an online system where children tend not to think about their surroundings because they feel accountable for their parents [7].

Law of the Republic of Indonesia Number 20 of 2003 concerning the National Education System, stated that "education is carried out democratically by upholding human rights, religious values, cultural values, and national pluralism, it is further noted that Education is organised as a process. cultivating and empowering students that last a lifetime."

Law Number 20 of 2003 concerning the National Education System article 37: "Citizenship Education is a compulsory subject for primary and secondary education curricula and compulsory subjects for higher education curricula. In this part of the explanation, it is emphasised again that "Citizenship education is intended to shape students into human beings who have a sense of nationality and love for the country."

Let's look at article 37 in the National Education System Law: "Citizenship education has a central role in educating Indonesians who respect differences in religion, ethnicity, caste and language. This is in line with national education objectives as stipulated in the Sikdisnas Law." Article 1 paragraph 1: "Education is a conscious and planned effort to create an atmosphere of learning and learning. Students actively develop their potential to have religious, spiritual strength, self-control, personality, intelligence, noble character, and skills needed by themselves, society, nation and state."

The habituation of the values of the nation's character is very suitable to be applied through. According to Winataputra and Budimansyah [8], Citizenship Education plays an important role in the mission of forming the nation's personality, namely as a conscious effort in "nation and character building". Citizenship education is very strategic for the survival of the nation and state. In the end, democracy cannot be separated from the aspects of knowledge, virtue and citizens and those who are elected to hold positions in society. Citizenship Education has the task of preparing students to become good and intelligent citizens and have a firm commitment to maintaining the diversity and integrity of the Indonesian nation. 
In addition, Budimansyah and Suryadi said that [9], "Citizenship education is a field of research that supports the national mission in an effort to educate the life of the Indonesian people through the path of "value-based education". The systematic framework of civic education is based on: First, citizenship is a curriculum subject aimed at developing individual potentials to become citizens who have good personalities from childhood, are responsible, participatory and intelligent. Second, Civics is a subject that covers aspects of cognitive, affective and psychomotor. Citizenship is confluent or pervasive and integrated with the ideas, values, concepts and morals of Pancasila, democratic citizenship, and defending the country. Third, Civics is developed in a structured manner as a learning subject in which there are learning experiences and values in the form of good behavior that need to be concreted in everyday life. This is the life demands of citizens in the life of society and the state.

From the above background, in this study, the researcher was particularly interested in researching: Improving Student Character during the Covid 19 Pandemic through Civic Education Learning.

Based on the descriptions and phenomena that have been presented in the above background, the following research questions are formulated :

1. How is the Civic Education learning process during the Covid Pandemic 19?

2. What are the efforts of Civic Education teachers in improving the character of students during the Covid 19 Pandemic?

\section{THEORETICAL REVIEW}

\subsection{Character Building during The Pandemic}

Character education is a conscious effort to realize virtue, namely objectively good human qualities, suitable for individuals, and good for society. The character education process is seen as a conscious and planned effort, not an effort that occurs by chance. On this basis, character education is a genuine effort to understand, shape, foster ethical values, both for oneself and all citizens" [10].

Character education is very well implemented, especially for students. Students become emotionally intelligent through systematic and continuously applied character formation. Emotional intelligence is essential for students to prepare for the future. Someone will successfully face all kinds of challenges, including those for academic success. In addition, character building is the key to personal success. Therefore, the teacher's personality is essential to influence the student's personality. Teachers help shape a student's character by giving examples and speaking, and providing good material, tolerances, and other relevant matters [11].

This goal means that the process of character education in schools must be linked to the educational process in the family. Character education in every school is expected to prevent the increase in juvenile delinquency among students. Character education aims to make a generation of superior and challenging students and have competitiveness by providing good character and religious training. Character education is critical to restoring the Indonesian nation's character, which is starting to fade. With the implementation of character education, it is hoped that it can solve social problems in society. The implementation of character education in schools can be implemented in learning activities, developing school culture and learning centers, extracurricular activities, and daily activities at home and in the community [12].

The success of character education during the COVID-19 pandemic experienced many obstacles, considering that learning in schools was carried out online or online. Online learning at the time of the current pandemic requires the cooperation of the role of parents. Learning activities carried out at home will facilitate the supervision of students' children and vice versa. The global era in the era of the COVID-19 pandemic is a challenge that has a direct impact on all lives, including students.

The development of student attitudes during the COVID-19 pandemic experienced many obstacles because the world, in general, experienced fundamental changes in habits or culture. To ward off changes in the student culture and behaviors during the COVID-19 pandemic, strengthening students' abilities in carrying out education character values can be used as an essential reference for realizing good habitual behavior for all parties, including students during the covid pandemic [13].

Exemplary is an essential aspect of character education during the covid 19 period considering character education as a form of personality that must be done in real life. Not only speaking, but must be proven in the form of exemplary carried out by all parties. All components in schools and the state and parents must continue to work together to create a pattern of behavior characterized by the Indonesian people during the COVID-19 pandemic. Instilling character education values during Covid 19 must use more innovative and effective strategies. So that students do not experience boredom seeing the pandemic conditions experiencing problems that can change student behavior [14].

They are planting character education in students when the COVID-19 outbreak is still a significant problem in the world. Character education is an urgent matter. The first and foremost education is in the family. The family also has an essential role in realizing learning and changes in students' attitudes. Parents must collaborate with schools and the community to develop educational patterns that emphasize character values during the current COVID-19 pandemic [15].

\subsection{Character Development through Civic Education}


Citizenship Education is a field of study that actualizes the national mission in an effort to improve the welfare of the Indonesian people. Sunarso et al. (2008: 12) suggests that: "The systematic framework of Civics was developed based on three paradigms. "First, Civics is a curriculum designed as a subject. It aims to develop individual potentials to become Indonesian citizens who are noble, intelligent, participatory, and responsible. Second, Civics is theoretically designed as a subject that includes cognitive, affective, and psychomotor dimensions. These dimensions are unified or integrated in the context of the substance of ideas, values, concepts, and morals of Pancasila, democratic citizenship, and defending the country. Third, Civics is designed pragmatically as a subject that emphasizes content that carries values and learning experiences. These learning experiences and values are actualized in every daily action and deed." [16].

By the objectives of Civics in the attachment of Permendiknas Number 22 of 2006 concerning Standard Contents, students can develop positively and democratically in placing themselves in line with the identity and character of the Indonesian nation, so that they can be together with other nations and countries. Civics' substance components, including civic knowledge, civic character, and civic skills, show that one of the missions carried out by Civics is character education. Character education which is the mission of Civics includes all aspects needed for the creation of intelligent, citizens who have skills, and are in accordance with the character of the Indonesian nation as mandated in the 1945 Constitution, namely intelligent citizens based on the substance of civic knowledge, skilled based on the substance of citizenship skills (civic skills), and citizens with character based on the substance of citizenship character (civic dispositions). These three aspects will be built-in students. It will develop into reasoning that will manifest in society, nation, and state by the ideals of building a civil society with the power of empowering citizens, with character material based on Indonesian society values [17].

Citizenship Education is a study of potential science to develop learning tasks that are rich in moral values. The development of value education in the school curriculum is new. Every teaching and guidance carried out by teachers involves a process of value awareness, namely the need for learning principles that automatically include scientific, moral, and religious values. Practical technical instructions that make it easier for teachers to assess the level of value formation. And teacher competency training in value development [18].

Citizenship knowledge and civic skills will establish civic character. They become attitudes and habits of everyday life. Nationalist, democratic, honest character, respecting diversity, obeying social rules, being aware of the rights and obligations of oneself and others are the values that exist in Civics learning. These 18 character values are extracted from culture, Pancasila, religion and national education goals. However, in this study, the focus of character values discussed is only two, namely independence and responsibility. Teachers are expected to apply these characters in Civics learning by using a cooperative approach model. Independent character means attitudes and behaviors that are not easy to depend on others in completing their tasks. In this case, it creates a classroom atmosphere that allows students to learn independently without depending on others [19].

In addition, the character of responsibility consists of a person's behavior and attitude in carrying out each of his obligations, as well as what is appropriate and appropriate to do to society, the environment and oneself, country, and God Almighty. Activities that arise in cooperative learning are students taking an active role in answering questions and providing comments to other groups [20].

\section{METHODS}

\subsection{Research Approach}

In this study, the researcher used a qualitative descriptive approach. This qualitative research uses a large number of efforts, including procedural questions and inquiries, collecting specific data from data sources, inductive analysis of data from specific topics from familiar topics, and interpreting the meaning of the data required.

\subsection{Research Focus}

Main focus of this research is to reveal some efforts of Civics teachers in improving the character of students during the Covid Pandemic 19.

\subsection{Research Sites}

The place of this research is Gonzaga Catholic Middle School, Tomohon, North Sulawesi.

\subsection{Research Instruments}

The instrument used in data collection to answer this research problem is to use a qualitative approach instrument as follows:

a. The primary instrument is the researcher himself, who uses analytic thinking techniques to create/verify the phenomenon under investigation. The primary informants of this study are local governments, religious leaders, forums for pagan harmony, traditional leaders, community leaders, and communities and immigrants.

b. Auxiliary instrument are tools or tools that help the research (the primary tool) conclude or verify the phenomenon under investigation.

\subsection{Data Collection Technique}

Data collection is the most strategic step in the research process. Data collection is the main goal of a research process. Data collection techniques used by researchers to obtain data are observation at the research 
site, interviews with teachers, documentation of research activities, and literature studies that support the research [21].

\subsection{Data Analysis Technique}

The results of this study were analyzed using the data analysis process proposed by Strauss and Corbin. In this analysis process, the three stages that are passed are "Open Coding, Axial Coding, and Selective Coding." These three stages are carried out simultaneously to build a valid and not mistaken theory. [22].

\subsection{Data Validity Testing}

When testing data validity, researchers use interval validity (reliability) in terms of truth values; in his application, external validity (transferability) is consistent. It can be examined in terms of reliability as well as objectivity (confirmability) on the naturalistic side [10]. Qualitative research emphasizes the validity of the data collected. From this, it can be inferred that the reliability of research data has a significant influence on the success of the research.

\section{RESULTS AND DISCUSSION}

\subsection{Civic Education Learning Process During The Covid Pandemic 19}

According to the results of research at the Gonzaga Tomohon Catholic Middle School, it was found that since the Covid Pandemic hit the whole world, including Indonesia, learning process has changed from offline to online. Based on interviews with Civic Education teachers, information was obtained that the Civic Education learning process at the Gonzaga Tomohon Catholic Middle School was entirely carried out online. Teaching and learning activities are carried out online, because the city of Tomohon is in the red zone status for the spread of Covid 19.

This method utilizes online networks and can lead to student creativity, especially in using online learning facilities. Students can create content or materials by utilizing items found around the house. Another way is to carry out all activities online. The use of this method is very beneficial for students who are in the red zone areas of the spread of Covid-19. Through the use of a complete online form, the process of delivering material in learning will run well and students do not need to be in school to learn.

The online learning process is an innovation in the world of education. This innovation was developed in order to solve the problem of learning resources and the availability of varied materials. Characteristics of students determine the success of a learning model [23]. According to Isman, "the online teaching and learning process is a form of internet integration in the teaching and learning process. The online teaching and learning process helps students to be flexible in learning according to their time and wherever they are." Via telephone, video, telephone, zoom, live chat, Whatsapp groups and zoom media. In the online learning process, students are not required to attend school, but access learning through internal facilities to attend classes. Students learn by accessing learning that has been provided in internet media [24], [23], [25].

Circular Letter Number 4 of 2020 concerning the Implementation of Education Policies in an Emergency Period for the spread of the corona virus disease (covid19) mandates that the Learning from Home Process be carried out with the following conditions: "(a) Studying at home with online/distance learning is implemented to provide students have a meaningful learning experience without demanding to complete all curriculum services for class progress and graduation; (b) Studying at home can focus on developing life skills, including the Covid 19 pandemic; (c) Learning at Home Learning activities and assignments may vary according to the interests and conditions of students, including considering access to remote homes/study facilities; (d). Evidence or self-made ball product activities in qualitative and valuable form from the teacher. The teacher is not obliged to give many points/values quantitatively."

\subsection{The Efforts Of Civic Education Teachers In Improving The Character Of Students During The Covid 19 Pandemic}

According to Civic Education teacher at the Gonzaga Tomohon Catholic Middle School, she has integrated some character values in the learning process. Character education is an effort to create a smart and good nationality (wise and good citizenship) or has noble morals and an Indonesian personality. The success of character education implies that learning is not necessarily seen from the perspective of the cognitive realm, but how the balance of the cognitive, affective, and psychomotor domains has the goal of realising a whole human being [26].

Integrating character values and developing learning materials requires teacher creativity and must still pay attention to the principles as stated by reference [27], as follows: (1). Principle of relevance: subject matter should be relevant to the achievement of competency standards and essential competencies. (2). The focus of consistency: if there are four kinds of crucial competencies that students must master, then the material that must be taught must also include four kinds (3). The sufficiency principle means that the material being taught should be sufficient in helping students master the essential competencies being taught. Learning as an educational activity to achieve graduate outcomes or competencies is an activity that is systematically planned and programmed to realise National Education's goals. A teacher is required to have the ability to plan lessons. [26] The Ministry of National Education explains that implementing character education in education units includes integration in subjects. Each subject contains a load of character values that need to be developed, made 
explicit, linked to the context of everyday life. Thus, learning character values is not only at the cognitive level but also on internalisation and actual practice in students' daily lives in society [28].

It concerns to see that the current generation has a personality that does not reflect good morals. Courtesy towards older people has begun to be neglected. Apart from politeness, the value of honesty and student responsibility also begins to disappear. The decline in the value of honesty visible when the students lied when asked the teacher, when you find the property of others in the class, taking out the trash, disembarking place, cheating, reasons and out of the classroom, and the grounds are not doing the work home. Character education in schools cannot be said to be non-existent at all. The existence of religious subjects, Pancasila moral education, guidance and counselling, is a tangible manifestation that schools have provided a portion of character education. Character education needs to have pleasant conditions and an atmosphere of intimacy between teachers and students.

The school's efforts to develop national identity have been challenged by new cultural elements, especially by the mass media. There is a conflict between students accepting what the school says and what they receive from cultural agents from outside the school, especially television. It seems that global evolution is taking place towards postmodern culture. The implication is that it is difficult for schools to perpetuate what has been cultivated in students without cooperation at the macro level with influential external cultural agents. The role of the teacher teaches Pancasila and citizenship education appropriately and adequately, and correctly. The family environment is also a factor that influences and determines the development of children. Suppose character education is instilled from an early age and continuously, such as getting used to being polite, responsible, respecting others and helping to help. In that case, students can become good role models for the next generation, which is where the involvement of parents in monitoring the development of children at home is essential. [29]

Because childhood is a period of formation of the foundation and personality that will determine the next child's experience, disrespectful behaviour by children with friends or teachers is brought from the home environment. Teachers need to make an effort or formulate a particular model in educating students to become future generations to improve the character of politeness, honesty and responsibility. In the design of this study, a model of value inculcation using a simple model already exists and has been applied in the school. Still, it is not too deep because, in essence, it is an exemplary model. Activity in implementing character education can be done through learning activities that innovative, like contextual learning. Character education with a contextual model is very suitable because contextual learning invites or connects the material studied with real life. Through contextual learning, students can get complete results not only in cognitive aspects but also in cognitive and psychomotor aspects. But we know that doing anything is not easy, and we also face the name with obstacles. The obstacle in instilling the values of politeness, honesty, and responsibility is the support of parents to participate in familiarising students with a sense of responsibility that needs to be improved. Students at home used to do something with the help of a household assistant so that these habits are carried up to the school [30].

Character education into the purpose of education that should be implemented for essentially all teachers as educators has the same goal of shaping the nation's character. Civic Education responsibility in the cultivation of character. Therefore, when implementing the curriculum in 2013, the balance of learning between cognitive, affective and psychomotor becomes output absolute as part of the nation's character education. Character education as an effort to cultivate understanding has three main functions. First, the function of the formation and development of potential students to be forward-thinking and behave by the principles of Pancasila. Second, the function of repair and strengthening. Character formation participates in developing citizens' potential and the state development into an advanced, independent, and prosperous state, strengthening and strengthening the roles of responsible families, academic units, communities, and governments. The third, the filtering function. Character formation has national cultural diversity and filters out the cultures of other countries that do not follow cultural values or national characters [31].

Furthermore, if talking about the implementation of character education through Civic Education at each type and level of education, it can be done in the following ways: [32]

First, character education is integrated into every Civic Education material; automatically, every given material is given the weight of character education. Educators compile learning plans by linking character values to indicators and teaching objectives and Civic Education teaching materials.

Second, the implementation of Civic Education learning with learning materials about character values is described in the teaching and learning process through 3 stages: introduction, core activities, and closing. In the introduction, character behaviour is presented through perceptions of students' daily activities or their experiences of behaviour and attitudes. Furthermore, the core activities are presented through examples or assignments to directly or indirectly learn various behaviours about character values with other students. Next, the closing activity concluded students have to master after learning the concept of character. So, in the Civic Education learning process, educators must create a character or character for each student.

Third, evaluation of Civic Education learning that applies character values is carried out on character 
building. By looking at the results of weekly assignments in the form of character/attitude improvement tasks made by students, it can be seen that changes and increases in themselves gradually every week. Based on observations of learning activities, it was found that the attitude change was quite good. For example, to form the character of responsibility, students who do not participate in group work are given mutually agreed upon penalties.

\section{CONCLUSION}

Civic Education is some of the subjects that contain the principles and values of national character that can be studied and applied. It is as guidelines in everyday life to create a society with good character, uphold the importance of unity and integrity, maintain the country's integrity, and protect the social and environmental live. The vital role of Civic Education is Education National Character. Teachers need to make an effort or formulate a particular model in educating students to become future generations to improve the character of politeness, honesty and responsibility.

During a pandemic, everything is done with the help of technology. Since the planting of the value of the character is done with the use of technology, the internet, zoom meetings and applications alike. The effort is made to train students to be religious, honest, responsible accountable, tolerant, discipline, and work hard. Character education with a contextual model is very suitable because contextual learning invites or connects the material being studied with real life. Through contextual learning, students can get complete results not only in cognitive aspects but also in cognitive and psychomotor aspects.

Teachers can do a strategy planting of character with integrating material Civic Education that begins with preparing a plan of learning by linking the value of the character on the indicator and the purpose of education and material resource. Implementation of the teaching of the introduction, activities of the core, and the cover is always in connecting with the value of the character. Evaluate the attitude of the character of the students who viewed the development as sustainable.

\section{AUTHORS' CONTRIBUTIONS}

Pangalila: Conceptualization, design, analysis, material support, providing final approval. Winoto: data interpretation, statistical analysis, writing, revising the manuscript.

\section{ACKNOWLEDGMENTS}

Thank you to the Dean of the Faculty of Social Sciences, Manado State University, who has supported this research. We also thank all those who have helped in completing this paper.

\section{REFERENCES}

[1]. L. Saputri and A. Muhibbin, Pembelajaran Pendidikan Pancasila Dan Kewarga Negaraan Kelas XI Melalui E-Learning Pada Masa Pandemi Covid-19 Di SMA Negeri Karya Sakti'. Universitas Muhammadiyah Surakarta, Surakarta, 2020, [Online]. Available: http://eprints.ums.ac.id/87797/10/Naskah Publikasi_Lili Saputri.pdf.

[2]. C. Sohrabi et al., 'World Health Organization declares global emergency: A review of the 2019 novel coronavirus (COVID-19)', Int. J. Surg., 76 (2020) 71-76. World Health Organization declares global emergency: A review of the 2019 novel coronavirus (COVID-19)

[3]. UNICEF, 'What is the novel coronavirus?', 2020. https:/www.unicef.org/indonesia/coronavirus/FA Q\#whatiscoronavirus (accessed Feb. 25, 2021).

[4]. A. Januar Mahardhani, 'Menjadi Warga Negara yang Baik pada Masa Pandemi Covid-19: Persprektif Kenormalan Baru', J. Pancasila dan Kewarganegaraan, 5(2), (2020) 65-76. DOI: 10.24269/jpk.v5.n2.2020.pp65-76

[5]. M. Giatman, S. Siswati, and I. Y. Basri, 'Online learning quality control in the pandemic Covid-19 era in Indonesia', J. Nonform. Educ., 6(2), (2020) $168-175$.

DOI: https://doi.org/10.15294/jne.v6i2.25594

[6]. Gusmaniarti, 'Membentuk karakter siswa di masa pandemi Covid-19', 2020. https://umsurabaya.ac.id/homepage/news_article?slug=mem bentuk-karakter-siswa-dimasa-pandemi-covid-19 (accessed Feb. 24, 2020).

[7]. N. Hidayah, 'Penanaman Nilai-Nilai Karakter Dalam Pembelajaran Bahasa Indonesia Di Sekolah Dasar', Terampil J. Pendidik. dan Pembelajaran Dasar, 2(2), (2015) 190-204.

[8]. U. S. Winataputra and D. Budimansyah, Civic education: Konteks, landasan, bahan ajar, dan kultur kelas. Bandung: Program Studi Pendidikan Kewarganegaraan SPS UPI, 2007.

[9]. D. Budimansyah and K. Suryadi, PKn dan masyarakat multikultural. Bandung: Program Studi Pendidikan Kewarganegaraan, Sekolah Pascasarjana, Universitas Pendidikan Indonesia, 2008.

[10]. Intania, E. V., \& Sutama, S., The role of character education in learning during the COVID-19 pandemic. Jurnal Penelitian Ilmu Pendidikan, Vol. 13 (2) (2020) 129-136.

[11]. Hasibuan, R., \& Rakhmawati, N. I. S., Information \& Communication Technology in Building Children Character During the Covid-19 Pandemic. Jurnal Obsesi: Jurnal Pendidikan Anak Usia Dini, 5(2) (2021) 1930-1942.

[12]. Zhang, Q., Narrative inquiry into online teaching of Chinese characters during the pandemic. International Journal of Chinese Language Teaching, 1(1) (2020) 20-34. 
[13]. Dike, D., Parida, L., \& Stevanus, I., Micro strategy and character educational transformation in elementary school during the covid-19 pandemic of sintang distric, west kalimantan province. European Journal of Molecular \& Clinical Medicine, 7(8) (2020) 775-786.

[14]. Elihami, E., Bibliometric analysis of islamic education learning loss in the COVID-19 pandemic. Linguistics and Culture Review, 5(S1) (2021) 851-859.

[15]. Setiawati, E., Ernawati, I., \& Sari, M. W., Internalization of Character Values Through School Culture: Comparative Study of the Pre and Corona Pandemic Period. Elementary Education Online, 20(1) (2021) 873-879.

[16]. El Faisal, E., \& Sulkipani, S., The Opportunities of Pancasila and Civic Education (PPKn) As an Instrument to Build of Students' environmental Caring Character. In Sriwijaya University Learning and Education International Conference, 3(1) (2018) 199-202.

[17]. Julkifli, J., Masrukhi, M., \& Susilaningsih, E., Learning Strategy of Pancasila and Citizenship Education on Students' Character Development. Journal of Primary Education, 9(1) (2020). 14-21.

[18]. Mardiana, M., Syahrir, M., \& Nurmutmainnah, N., The Influence of Pancasila and Citizenship Education Teachers in Instilling Moral Ethics to Build National Character in Madrasah Aliyah Syekh Yusuf Sungguminasa. JED (Journal of Etika Demokrasi), 6(1) (2021) 124-137.

[19]. Haryati, T., Widodo, J., \& Masrukhi, M., The Model Of Integrated Character Education Curriculum Management At LPTK. The Journal of Educational Development, 4(2) (2016) 146-155.

[20]. Dianti, P., Waluyati, S. A., \& Fatihah, H, The Development of Value-Based Democratic Education Textbook at Pancasila and Civic Education Study Program FKIP UNSRI. In International Conference on Progressive Education (ICOPE 2019) (2020) 205-208. Atlantis Press

[21]. Sugiyono, Metode Penelitian Kombinasi (Mixed Methods). Bandung: Alfabeta, 2016.

[22]. A. Strauss and J. Corbin, Dasar-Dasar Penelitian Kualitatif: Tatalangkah dan Teknik-Teknik Teoritisasi Data. Yogyakarta: Pustaka Pelajar, 2003.
[23]. W. A. F. Dewi, 'Dampak Covid-19 terhadap implementasi pembelajaran daring di Sekolah Dasar', Edukatif J. Ilmu Pendidik., 2(1) (2020) 5561.

[24]. A. Anugrahana, 'Hambatan, Solusi dan Harapan: Pembelajaran Daring Selama Masa Pandemi Covid-19 Oleh Guru Sekolah Dasar', Sch. J. Pendidik. dan Kebud., 10(3) (2020) 282-289.

[25]. M. Nakayama, H. Yamamoto, and R. Santiago, 'The Impact of Learner Characteristics on Learning Performance in Hybrid Courses among Japanese Students.', Electron. J. E-Learning, 5(3) (2007) 195-206.

[26]. I. W. E. Santika, 'Pendidikan karakter pada pembelajaran daring', Indones. Values Character Educ. J., 3(1), (2020) 8-19.

[27]. K. Komalasari and D. Saripudin, 'The influence of living values education-based civic education textbook on student's character formation', Int. J. Instr., 11(1) (2018) 395-410, doi: 10.12973/iji.2018.11127a.

[28]. P. K. Gellert, 'Optimism and education: The new ideology of development in Indonesia', J. Contemp. Asia, 45(3) (2015) 371-393. DOI: http://dx.doi.org/10.1080/00472336.2014.978352

[29]. B. Martin, M. M. Kelly, and E. Towner-Thyrum, 'Adoptive family adjustment and its relation to perceived family environment', Adopt. Q., 3(1), (1999) 49-60, https://doi.org/10.1300/J145v03n01_04

[30]. A. Ubaedillah, 'Civic education for muslim students in the era of democracy: Lessons learned from Indonesia', Rev. Faith Int. Aff., 16(2) (2018) 50-61. https://dx.doi.org/10.2991/icsps17.2018.83

[31]. R. A. Sihombing and P. S. Lukitoyo, 'Peranan Penting Pancasila Dan Pendidikan Kewarganegaraan Sebagai Pendidikan Karakter di Masa Pandemi Covid-19', Jurnal Pendidikan Kewarganegaraan Undiksha, 9(1) (2021) 49-59. https://ejournal.undiksha.ac.id/index.php/J JPP

[32]. B. Juliardi, 'Implementasi Pendidikan Karakter Melalui Pendidikan Kewarganegaraan', J. Bhinneka Tunggal Ika, 2(2) (2015) 3. https://doi.org/10.36706/jbti.v2i2.4581. 